Nigerian Journal of Environmental Sciences and Technology (NIJEST)

www.nijest.com

ISSN (Print): 2616-051X ｜ＩSSN (electronic): 2616-0501

Vol 4, No. 1 March 2020, pp 87 - 96

\title{
Impact of Urbanizing Ovia-North East on the Quality of Groundwater using Water Quality Index
}

\author{
Rawlings A.* and Ikediashi A. I. \\ Department of Civil Engineering, Faculty of Engineering, University of Benin, Benin City, Edo State, Nigeria \\ Corresponding Author: *seghosimeh@gmail.com
}

https://doi.org/10.36263/nijest.2020.01.0180

\begin{abstract}
Due to increasing population and industrialization in urban areas, the environment has become so vulnerable as a result of unhygienic practise by the populace (particularly in developing country). Thus, making groundwater to be more vulnerable to pollutants from the environment. In this study, groundwater samples were collected from twelve different boreholes (six domestic boreholes and six bakery boreholes) in Ovia North-East Local Government Areas and assessed for their suitability in domestic and industrial purposes. These samples were collected between September and October, 2019 (peak of rainy season). The samples were analysed for fourteen physiochemical parameters, namely: pH, Electrical Conductivity (EC), Total Dissolved Solids (TDS), Turbidity, Bicarbonate $\left(\mathrm{HCO}_{3}^{-}\right)$, Chloride $(\mathrm{Cl})$, Ammonium Nitrogen $\left(\mathrm{NH}_{4} \mathrm{~N}\right)$, Total Hardness $(\mathrm{TH})$, Temperature, Odour, Iron (Fe), Zinc ( $\mathrm{Zn})$, Lead $(\mathrm{Pb})$ and Cadmium $(\mathrm{Cd})$. All the laboratory analyses were conducted in accordance with the techniques described by American Public Health. Statistical analyses such as correlation matrix (Pearson's Correlation) and water quality index (WQI) were used in this study. Results of physiochemical analysis revealed that of all the parameters examined, $\mathrm{pH}, \mathrm{Pb}$ and $\mathrm{Cd}$ were not within acceptable limits. The correlation matrix indicated that TDS shows a highly positive correlation (0.99) between $E C$ and $\mathrm{NH}_{4} \mathrm{~N}$ respectively and also Temperature shows a highly negative correlation (0.80) between EC, TDS and $\mathrm{NH}_{4} \mathrm{~N}$ respectively. The WQI indicated that the groundwater samples ranged from excellent to good indicating that the water is fit for drinking, domestic and industrial purpose. The physiochemical and correlation analyses revealed that the quality of groundwater in Ovia- North East LGA has slightly deteriorated and might be prone to contamination (by anthropogenic activities). Hence, it is recommended that there should be regular monitoring of the groundwater quality so as to sustain and improve the water quality and that the water should be treated before use.
\end{abstract}

Keywords: Groundwater, Pollution, Physiochemical parameter, Acceptable limit, Water Quality Index

\subsection{Introduction}

Developing countries (particularly in Sub-Sahara Region) are faced with the problem of accessing portable water and this is attributed to the fact that they get their water from poor sources. Surface water which is an easy source of water mainly used in developing countries get easily contaminated due to its exposed nature, hence the people in these countries have started resorting to ground water as their major source of portable water due to its low levels of impurities (Akpoveta, 2011; Patil et al., 2015 ) and the populace of Benin City are not left out on this. Therefore, groundwater has become a vital renewable resource that needs to be monitored and protected (Usman et al., 2014).

Groundwater is the water found underground in the cracks and spaces in the soil, sand and rock. It is stored in and moves slowly through geologic formations of soil, sand and rocks called aquifers (NGWA, 2019). Groundwater supplies are replenished, or recharged, by rain and snow melt that seeps down into the cracks and crevices beneath the land's surface (Mukherji, 2006). Groundwater serve various purposes including public and domestic water supply system, irrigation and livestock watering, industrial, commercial and mining purposes (USEPA, 2002, Usman et al., 2014). When groundwater is contaminated, its quality cannot be restored by controlling or stopping the contaminant 
from the source (Khwaja and Aggarwal, 2014) and as such it may become unusable for decades leading to loss of well-water supplies (Nicole, et al., 2019) and migration of contaminants to other water bodies such as lakes and rivers as groundwater passes through the hydrologic circle (Conant $e t$ al., 2004). Contaminated water has a great potential for transmitting a wide variety of diseases (Ogbeifun et al., 2019). About $80 \%$ of the diseases that affect the global population today and more than one-third of the deaths in the developing countries are all attributed to contaminated water (Adegbite et al., 2018). These diseases are as a result of drinking contaminated water (Chan et al., 2007). Thus, tremendous concern is now being raised on the deterioration of groundwater quality considering the fact that it is the major source of portable water supply.

As the population of Nigeria continue to grow, a lot of people are increasingly moving from rural to urban centres, making cities with greater population density to be larger than ever before. Benin City is one of such cities as it comprises of different local government areas (LGAs), including Ikpoba Okha, Oredo, Egor and Ovia North East Local government areas (Balogun and Orimoogunje, 2015) each of which is experiencing a tremendous increase in Urbanization. Lately, Ovia North East LGA of Benin City in Edo State, Nigeria has been experiencing rapid urbanization which is one of factor that is responsible for rapid deterioration of water quality (Ogendegbe and Akinbile, 2004; Christopher and Olatunji, 2018). Increased population, urbanization and industrialization has been attributed to increased anthropogenic activities which has been identified as major source of pollution of water bodies (Kumar and Kumar, 2013). It has been shown that anthropogenic activities in all sectors impact and alter the natural water cycle and subsequent groundwater quality. These alterations can largely affect the environment and human health (Nicole et al., 2019).

As Ovia North East LGA is experiencing rapid urbanization, human activities (including soil fertility remediation, indiscriminate refuse and waste disposal, and the use of septic tanks, soak-away pits and pit latrines) and industrial activities are on the increase. These activities are capable of producing leachates into the groundwater formation that serve as a major source of drinking water to the inhabitants in this LGA. And this often renders the water unfit for use. Hence, it is imperative to regularly monitor the water quality of water resources in order to safeguard public health and secure water resources for portable water supply. Although numerous studies have assessed the groundwater quality in southern Nigeria (Erah et al., 2002; Omoigberale et al., 2009; Akpoveta et al., 2011; Orjiekwe et al., 2013; Omorogieva et al., 2016; Adegbite et al., 2018; Foka et al., 2018; Ogbeifun et al., 2019). However, no study has been reported on the groundwater quality in Ovia North East despite the rapid urbanization that has occurred in this area over the years. Therefore, this study aimed at assessing the impact of urbanizing Ovia North East LGA of Benin City on the quality of groundwater using water quality index. This study will provide data and information that will be useful to the government and other authorities concerned for future water monitoring in the LGA.

\subsection{Methodology}

\subsection{Study area}

Ovia North-East Local Government Area has its headquarters in Okada town and it has an area of 2,301 square kilometres (Akinbo and Okaka, 2010). It is bounded by longitude $5^{\circ} 45^{\prime}$ and $6^{\circ} 15^{\prime}$ east and latitude $5^{\circ} 15^{\prime}$ and $6^{\circ} 45^{\prime}$ north of the central province of Edo state. The main river, Ovia River flows through all the communities in the LGA (Akinbo and Okaka, 2010). The Local Government Area (Ovia North East) is situated in Benin City and Benin City is located within the rainforest zone of Nigeria with mean annual rainfall in the range of $1500 \mathrm{~mm}$ to $2500 \mathrm{~mm}$ and the mean monthly temperature varying from $25^{\circ} \mathrm{C}$ to $28^{\circ} \mathrm{C}$ (http://www.edoworld.net/Edotourismweather.html). The Benin Region is underlain by sedimentary formation of the South Sedimentary Basin (Ikhile, 2016) and it constitute part of the Benin formation which is made up of over $90 \%$ massive, porous, coarse sand with thick clay/shale interbeds having high groundwater retention capacity (Adegbite et al., 2018). The geology is generally marked by top reddish earth, composed of ferruginized or literalized clay sand (Ikhile, 2016). Benin City has two distinct seasons. These are the wet (rainy) season and the dry season. The rainy season occurs between the months of March and October with a short break in August. The dry season on the other hand lasts from November to February with dry harmattan winds between December and February, but with the effect of global warming and climate change, rains have been observed to fall irregularly almost in every month of the year with double peak periods in 
July and September. At present the population of Benin City is estimated to be about 1.75 million (projected from 2015 population figures).

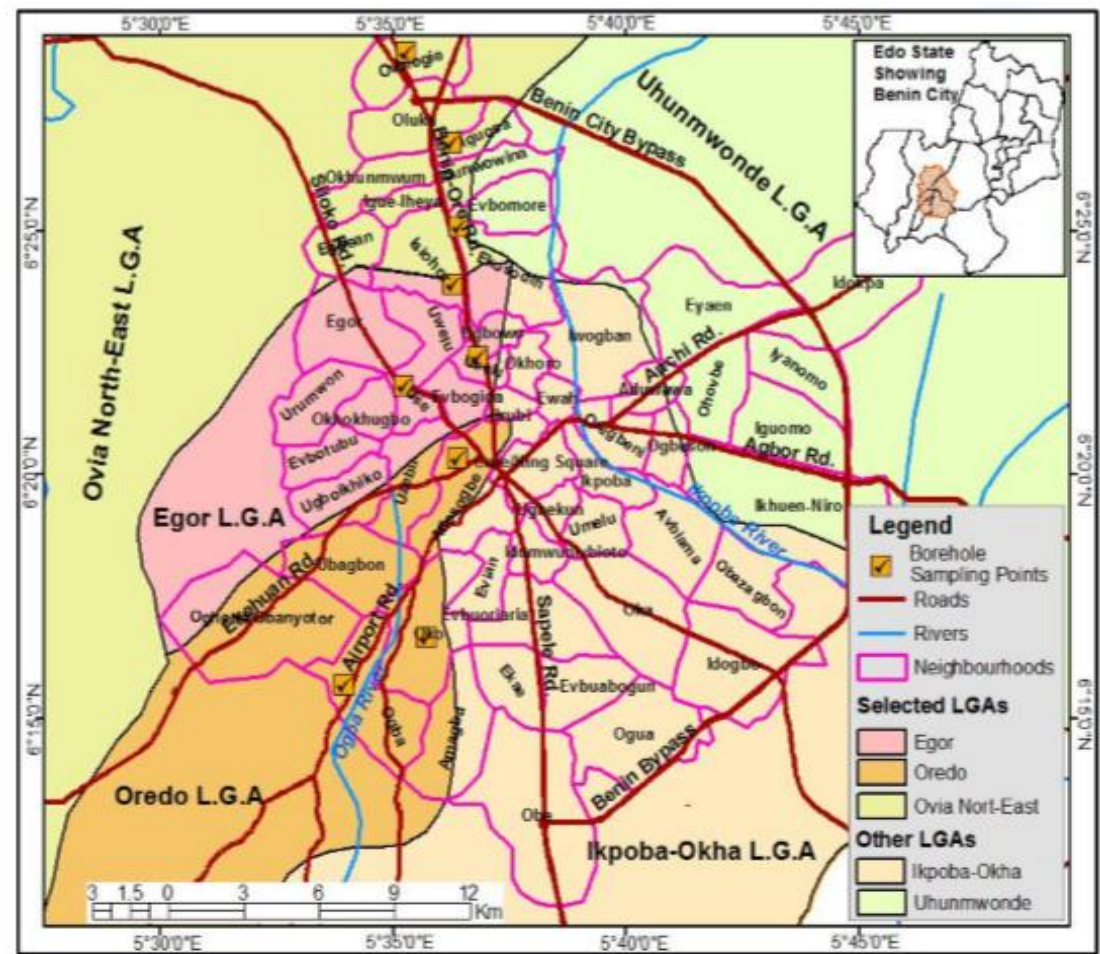

Figure 1: Map of Benin City showing Ovia North-East LGA and other Local Government Areas (Source: Ogbeifun et al., 2019)

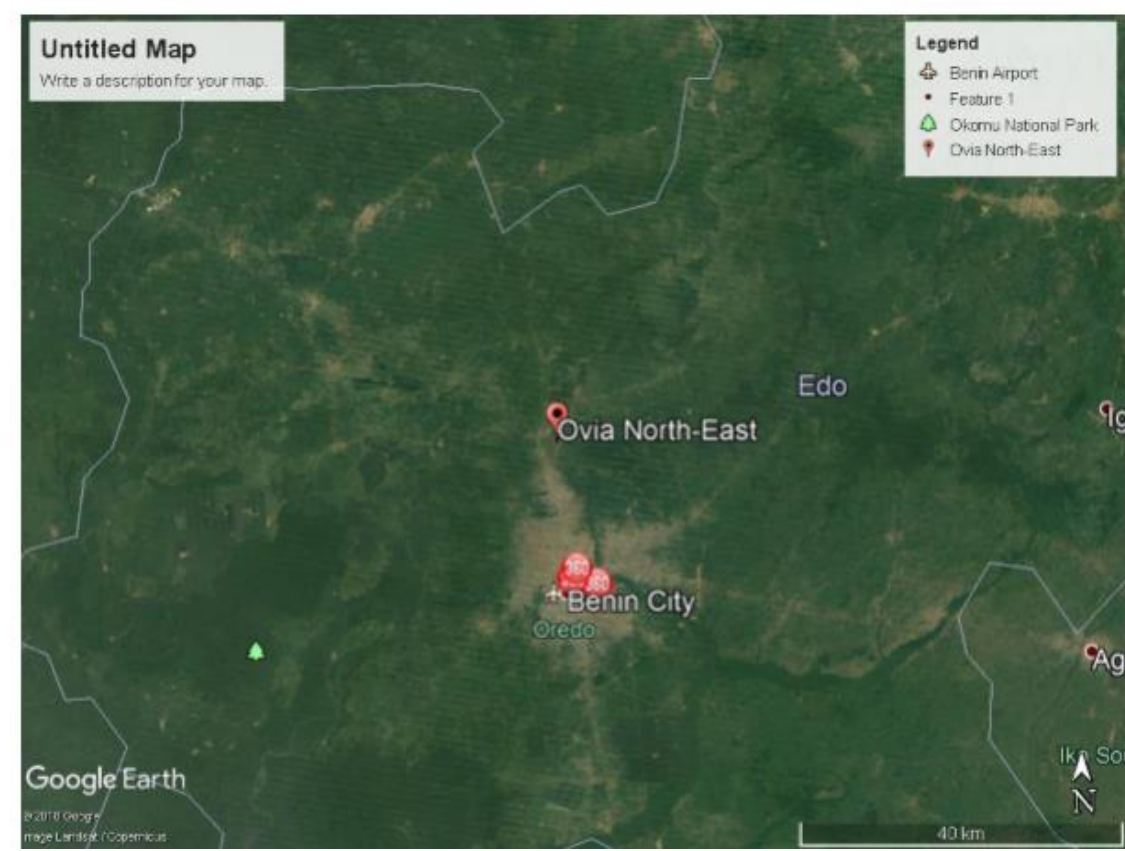

Figure 2: A map showing the location of Ovia-North East LGA (Source: Google Earth)

\subsection{Sample collection and physiochemical analysis}

Groundwater samples were collected from twelve different boreholes (through tap: six samples from domestic boreholes and six samples from bakery boreholes) in Ovia North-East LGA. These samples were collected towards the ending of September and beginning of October, 2019 (peak of rainy season). The samples were labelled and transported to the laboratory for analysis. It was ensured that the sample bottles were properly cleaned and sterilized before use. The samples were analysed for fourteen physiochemical parameters, namely: $\mathrm{pH}$, Electrical Conductivity (EC), Total Dissolved Solids (TDS), Turbidity, Bicarbonate $\left(\mathrm{HCO}_{3}^{-}\right)$, Chloride $(\mathrm{Cl})$, Ammonium Nitrogen $\left(\mathrm{NH}_{4} \mathrm{~N}\right)$, Total 
Hardness $(\mathrm{TH})$, Temperature, Odour, Iron $(\mathrm{Fe})$, Zinc $(\mathrm{Zn})$, Lead $(\mathrm{Pb})$ and Cadmium $(\mathrm{Cd})$. All laboratory analyses were conducted in accordance with the techniques described by American Public Health (APHA, 1985 and 2005) and the methods adopted for analysing the groundwater quality parameters are shown in Table 1.

Table 1: Analytical methods for water quality parameters

\begin{tabular}{ll}
\hline Parameters & Analytical Methods \\
\hline $\mathrm{pH}$ & Flame Photometric Method \\
Electrical Conductivity (EC) & Flame Photometric Method \\
Total Dissolved Solids (TDS) & Flame Photometric Method \\
Turbidity & Spectronic 20D ${ }^{+}$Spectrophotometry Method \\
Bicarbonate $\left(\mathrm{HCO}_{3}{ }^{-}\right)$ & Titrimetric Method \\
Chloride $(\mathrm{Cl})$ & Titrimetric Method \\
Ammonium Nitrogen $\left(\mathrm{NH}_{4} \mathrm{~N}\right)$ & Titrimetric Method \\
Total Hardness $(\mathrm{TH})$ & Titrimetric Method \\
Temperature & Thermometer Method \\
Odour & Human Olfaction Method \\
Iron $(\mathrm{Fe})$ & Spectrophotometry Method (Atomic Absorption Spectrophotometer) \\
Zinc $(\mathrm{Zn})$ & Spectrophotometry Method (Atomic Absorption Spectrophotometer) \\
Lead $(\mathrm{Pb})$ & Spectrophotometry Method (Atomic Absorption Spectrophotometer) \\
Cadmium $(\mathrm{Cd})$ & Spectrophotometry Method (Atomic Absorption Spectrophotometer) \\
\hline
\end{tabular}

\subsection{Statistical analysis}

Primary data (groundwater quality data from laboratory analysis) were analysed statistically and these analyses include correlation matrix and water quality index (WQI). The correlation matrix involves Pearson's correlation using statistical package for the social sciences (SPSS) and the water quality index (WQI) was carried out using Microsoft excel (2013 version). According to Gogtay and Thatte (2017), the end result of a correlation analysis is a Correlation coefficient whose values range from -1 to +1 . This value shows how good the correlation is (and not how steep the line is) and whether it is positive or negative (Mohamed, 2015). WQI reduces the bulk of data into a single value in order to express the data in a simplified and logical form and demonstrate annual cycles, spatial and temporal variation and trends in water quality at low concentrations (Shweta et al., 2013). Pius et al. (2012) describe WQI as a single unit number (of less than 100) that sorts out the quality of water source. The maximum permissible value of this WQI is 100 (for the water to be fit for drinking), thus values greater than 100 indicates signs of pollution and as such the water becomes unfit for human consumption (Mohammad and Amba, 2018). Weight arithmetic WQI method classified the water quality according to the degree of purity, using the most commonly measured water quality variables (Paiu and Breaban, 2010). The weighted arithmetic index method from Brown et al. (1972), Tyagi et al. (2013) and Egun and Ogiesoba-Eguakun (2018) was used for the calculation of the WQI of the groundwater. From this method, the quality rating $\left(q_{n}\right)$ was calculated using the following equation:

$q_{n}=100 \frac{\left[V_{n}-V_{i}\right]}{\left[S_{n}-V_{n}\right]}$

where,

$q_{n}=$ Quality rating

$V_{n}=$ observed value

$V_{i}=$ ideal value

$S_{n}=$ Standard value for the nth parameters

$W_{n}=$ Unit weight for the nth parameters, which is $\frac{K}{S_{n}}$

$\mathrm{K}=$ constant for proportionality.

The overall WQI was then calculated by the equation: 
$W Q I=\frac{\sum q_{n} \times W_{n}}{\sum W_{n}}$

Based on the WQI values gotten from the above equation, the groundwater type was classified as indicated in Table 2.

Table 2: Water quality rating based on the weighted arithmetic water quality index method

(Tyagi et al., 2013; Egun and Ogiesoba-Eguakun, 2018)

\begin{tabular}{ll}
\hline Range & Rating of Water Quality \\
\hline $0-25$ & Excellent \\
$25-50$ & Good \\
$51-75$ & Poor \\
$76-100$ & Very poor \\
$>100$ & Unsuitable for drinking \\
\hline
\end{tabular}

\subsection{Results and Discussion}

Results from both physiochemical and statistical analyses are presented in Tables 3, 4, 5, 6 and 7. The Comparison of Physiochemical Parameter Analysis with Nigerian Standard for Drinking Water Quality (NSDWQ, 2015) and World Health Organisation (WHO, 2011) Standard are presented in Table 3. Table 4 shows the Physiochemical Parameters Analysis of Groundwater Quality in OviaNorth East LGA and Table 5 and 6 shows Pearson's Correlation Matrix of both Bakery and Domestic Boreholes (in Ovia- North East LGA) Water Quality Parameters. Table 7 present the results of WQI of the groundwater samples (both bakery and domestic).

Table 3: Comparison of physiochemical parameter analysis with NSDWQ (2015) and WHO (2011)

\begin{tabular}{|c|c|c|c|c|}
\hline Parameters & $\begin{array}{l}\text { Acceptable Limit } \\
\text { NSDWQ (2015) }\end{array}$ & $\begin{array}{l}\text { Acceptable Limit } \\
\text { WHO (2011) }\end{array}$ & $\begin{array}{l}\text { Groundwater } \\
\text { Analysis }\end{array}$ & Samples \\
\hline $\mathrm{pH}$ & $6.5-8.5$ & $6.5-8.5$ & $4.7-5.5$ & \\
\hline $\mathrm{EC}(\mu \mathrm{S} / \mathrm{cm})$ & 1500 & 1500 & $11.2-32.4$ & \\
\hline TDS (mg/L) & 500 & 500 & $5.5-20$ & \\
\hline Turbidity (NTU) & 5 & $1-5$ & ND & \\
\hline $\mathrm{HCO}_{3}^{-}(\mathrm{mg} / \mathrm{L})$ & 500 & 500 & $10.1-42.7$ & \\
\hline $\mathrm{Cl}(\mathrm{mg} / \mathrm{L})$ & 250 & 250 & $35.5-68.6$ & \\
\hline $\mathrm{NH}_{4} \mathrm{~N}(\mathrm{mg} / \mathrm{L})$ & 0.5 & 0.5 & $0.114-0.480$ & \\
\hline $\mathrm{TH}(\mathrm{mg} / \mathrm{L})$ & 200 & 200 & $0.47-1.88$ & \\
\hline Temperature $\left({ }^{\circ} \mathrm{C}\right)$ & Ambient & 30 & $25.2-27.4$ & \\
\hline Odour & Odourless & Odourless & Odourless & \\
\hline $\mathrm{Fe}(\mathrm{mg} / \mathrm{L})$ & 0.3 & 0.3 & $0.311-1.633$ & \\
\hline $\mathrm{Zn}(\mathrm{mg} / \mathrm{L})$ & 3 & 3 & $0.265-0.741$ & \\
\hline $\mathrm{Pb}(\mathrm{mg} / \mathrm{L})$ & 0.01 & 0.01 & $0.030-0.111$ & \\
\hline $\mathrm{Cd}(\mathrm{mg} / \mathrm{L})$ & 0.003 & 0.003 & $0.008-0.054$ & \\
\hline
\end{tabular}

EC: Electrical Conductivity; TDS: Total Dissolved Solids; $\mathrm{HCO}_{3}^{-}$: Bicarbonate; Cl: Chloride; $\mathrm{NH}_{4} \mathrm{~N}:$ Ammonium Nitrogen; TH: Total Hardness; Fe: Iron; Zn: Zinc; Pb: Lead; Cd: Cadmium; ND: Not Detected

Table 4: Physiochemical parameter analysis of groundwater quality in Ovia-North East LGA

\begin{tabular}{|c|c|c|c|c|c|c|c|c|c|c|c|c|c|c|}
\hline $\begin{array}{l}\text { Sampling } \\
\text { Points }\end{array}$ & pH & $\begin{array}{l}\text { EC } \\
(\mu \mathrm{S} / \mathrm{cm})\end{array}$ & $\begin{array}{l}\text { Temp. } \\
\left({ }^{\circ} \mathrm{C}\right)\end{array}$ & $\begin{array}{l}\text { Turb. } \\
\text { (NTU) }\end{array}$ & Odour & $\begin{array}{l}\text { TDS } \\
(\mathrm{mg} / \mathrm{L})\end{array}$ & $\begin{array}{l}\mathrm{HCO}_{3}^{-} \\
(\mathrm{mg} / \mathrm{L})\end{array}$ & $\begin{array}{l}\mathrm{Cl} \\
(\mathrm{mg} / \mathrm{L})\end{array}$ & $\begin{array}{l}\mathrm{NH}_{4} \mathrm{~N} \\
(\mathrm{mg} / \mathrm{L})\end{array}$ & $\begin{array}{l}\mathrm{Fe} \\
(\mathrm{mg} / \mathrm{L})\end{array}$ & $\begin{array}{l}\mathrm{Zn} \\
(\mathrm{mg} / \mathrm{L})\end{array}$ & $\begin{array}{l}\text { Pb } \\
(\mathrm{mg} / \mathrm{L})\end{array}$ & $\begin{array}{l}\text { Cd } \\
(\mathrm{mg} / \mathrm{L})\end{array}$ & $\begin{array}{l}\text { TH } \\
(\mathrm{mg} / \mathrm{L})\end{array}$ \\
\hline $\mathrm{DBH}_{1}$ & 5.3 & 11.2 & 27.4 & ND & Odourless & 5.5 & 10.1 & 35.5 & 0.114 & 0.311 & 0.187 & 0.030 & 0.008 & 0.47 \\
\hline $\mathrm{DBH}_{2}$ & 5.1 & 16.9 & 27.1 & ND & Odourless & 8.4 & 18.3 & 35.5 & 0.212 & 0.501 & 0.300 & 0.055 & 0.015 & 0.94 \\
\hline $\mathrm{DBH}_{3}$ & 5.1 & 15.3 & 27.1 & ND & Odourless & 7.7 & 12.2 & 43.2 & 0.204 & 0.447 & 0.285 & 0.051 & 0.018 & 0.91 \\
\hline $\mathrm{DBH}_{4}$ & 4.7 & 14.3 & 26.8 & ND & Odourless & 7.2 & 12.2 & 35.5 & 0.192 & 0.332 & 0.271 & 0.047 & 0.011 & 0.78 \\
\hline $\mathrm{DBH}_{5}$ & 4.7 & 27.9 & 26.4 & ND & Odourless & 12.6 & 30.5 & 50.9 & 0.360 & 1.480 & 0.584 & 0.094 & 0.036 & 1.41 \\
\hline $\mathrm{DBH}_{6}$ & 5.3 & 19.2 & 26.4 & ND & Odourless & 9.6 & 18.3 & 43.2 & 0.276 & 0.631 & 0.318 & 0.045 & 0.010 & 1.77 \\
\hline $\mathrm{BBH}_{1}$ & 4.7 & 20.5 & 26.1 & ND & Odourless & 10.3 & 18.3 & 43.2 & 0.281 & 0.754 & 0.364 & 0.057 & 0.025 & 1.14 \\
\hline $\mathrm{BBH}_{2}$ & 4.8 & 20.7 & 26.3 & ND & Odourless & 10.3 & 18.3 & 43.2 & 0.284 & 1.351 & 0.571 & 0.084 & 0.032 & 1.24 \\
\hline $\mathrm{BBH}_{3}$ & 4.9 & 11.8 & 25.7 & ND & Odourless & 5.9 & 12.2 & 35.5 & 0.123 & 0.314 & 0.265 & 0.038 & 0.010 & 0.67 \\
\hline $\mathrm{BBH}_{4}$ & 4.8 & 40.1 & 25.3 & ND & Odourless & 20.0 & 42.7 & 68.6 & 0.480 & 1.633 & 0.741 & 0.111 & 0.054 & 1.88 \\
\hline $\mathrm{BBH}_{5}$ & 5.3 & 27.2 & 26.2 & ND & Odourless & 13.6 & 18.3 & 43.2 & 0.351 & 0.901 & 0.515 & 0.070 & 0.028 & 1.30 \\
\hline $\mathrm{BBH}_{6}$ & 5.5 & 32.4 & 25.2 & ND & Odourless & 16.1 & 36.6 & 68.6 & 0.370 & 1.532 & 0.666 & 0.102 & 0.041 & 1.75 \\
\hline
\end{tabular}

DBH: Domestic Borehole; BBH: Bakery Borehole; Temp.: Temperature; Turb.: Turbidity 
Results from Table 3 and 4 shows that all parameters examined were within NDSWQ and WHO acceptable limits except for $\mathrm{pH}$, Lead $(\mathrm{Pb})$ and Cadmium $(\mathrm{Cd})$. This indicates that the groundwater is slightly acidic and contains high amount of heavy metals $(\mathrm{Pb}$ and $\mathrm{Cd})$. Lower values of $\mathrm{pH}$ might be attributed to anthropogenic activities (pollution) within the study area and these values might be responsible for the increased heavy metals $(\mathrm{Pb}$ and $\mathrm{Cd})$ in the groundwater, as too high or low $\mathrm{pH}$ is known to affect the solubility and toxicity of heavy metals. The acidic nature of groundwater quality in Benin City has been noted by several researchers (Omoigberale et al., 2009; Orjiekwe et al., 2013; Ogbeifun et al., 2019). Though pH has no direct effect on human (Ogbeifun et al., 2019) but all the biochemical reactions are however $\mathrm{pH}$ dependent. Acidic water might occur naturally as a result of mixture of volcanic gases, gaseous emanations in geothermal areas (Osei, 2004) or due to alteration of groundwater by anthropogenic activities as stated by (Umar and Absar, 2003) and may result in serious health complications such as irritation in the eyes, skin and mucous membrane (Karunakaran, 2008). Also lower $\mathrm{pH}$ levels enhance the corrosive characteristics of water resulting in contamination of drinking water and adverse effect on its taste and appearance (WHO, 2007; Egun, and OgiesobaEguakun, 2018). Higher levels of heavy metals ( $\mathrm{Pb}$ and $\mathrm{Cd}$ ) in drinking water pose threat to human health (Erah et al., 2002). In contrast, Adegbite et al. (2018) show that the level of Lead (Pb) in the groundwater in Egbeta was within WHO acceptable limit, this might be attributed to the fact that at the time of assessment, this area has not experience rapid urbanization and as such human activities was not on the increase. Higher levels of $\mathrm{Pb}$ and $\mathrm{Cd}$ in groundwater quality in some areas in Benin City have also been noted by some researchers (Omoigberale et al., 2009 and Erah et al., 2002).

Table 5: Pearson's correlation matrix for bakery boreholes water quality parameters

\begin{tabular}{|c|c|c|c|c|c|c|c|c|c|c|c|c|}
\hline Parameters & pH & EC & Temp. & TDS & $\mathrm{HCO}_{3}^{-}$ & $\mathrm{Cl}$ & $\mathrm{NH}_{4} \mathrm{~N}$ & $\mathrm{Fe}$ & $\mathrm{Zn}$ & $\mathbf{P b}$ & Cd & TH \\
\hline pH & 1 & & & & & & & & & & & \\
\hline $\mathrm{EC}(\mu \mathrm{S} / \mathrm{cm})$ & -0.4842 & 1 & & & & & & & & & & \\
\hline Temp $\left({ }^{\circ} \mathrm{C}\right)$ & 0.4064 & -0.8028 & 1 & & & & & & & & & \\
\hline TDS (mg/L) & -0.4531 & 0.9934 & -0.8380 & 1 & & & & & & & & \\
\hline $\mathrm{HCO}_{3}-(\mathrm{mg} / \mathrm{L})$ & -0.4531 & 0.9804 & -0.7265 & 0.9654 & 1 & & & & & & & \\
\hline $\mathrm{Cl}(\mathrm{mg} / \mathrm{L})$ & -0.2988 & 0.8682 & -0.7000 & 0.8592 & 0.7789 & 1 & & & & & & \\
\hline $\mathrm{NH}_{4} \mathrm{~N}(\mathrm{mg} / \mathrm{L})$ & -0.4583 & 0.9767 & -0.8960 & 0.9924 & 0.9289 & 0.8647 & 1 & & & & & \\
\hline $\mathrm{Fe}(\mathrm{mg} / \mathrm{L})$ & 0.4832 & 0.9713 & -0.6926 & 0.9388 & 0.9646 & 0.8767 & 0.9049 & 1 & & & & \\
\hline $\mathrm{Zn}(\mathrm{mg} / \mathrm{L})$ & -0.6020 & 0.9824 & -0.7351 & 0.9606 & 0.9610 & 0.8598 & 0.9376 & 0.9809 & 1 & & & \\
\hline $\mathrm{Pb}(\mathrm{mg} / \mathrm{L})$ & -0.6770 & 0.9354 & -0.6208 & 0.9109 & 0.9240 & 0.7892 & 0.8784 & 0.9349 & 0.9770 & 1 & & \\
\hline $\mathrm{Cd}(\mathrm{mg} / \mathrm{L})$ & 0.6165 & 0.8782 & -0.4872 & 0.8375 & 0.8599 & 0.7954 & 0.7954 & 0.9225 & 0.9411 & 0.9707 & 1 & \\
\hline TH (mg/l) & 0.3284 & 0.9731 & -0.5546 & 0.9718 & 0.9405 & 0.9408 & 0.9562 & 0.9303 & 0.4595 & 0.9658 & 0.9744 & 1 \\
\hline Min & 4.700 & 11.800 & 25.200 & 5.900 & 12.200 & 35.500 & 0.1230 & 0.3140 & 0.2650 & 0.0380 & 0.0100 & 0.6700 \\
\hline $\operatorname{Max}$ & 5.500 & 40.100 & 26.300 & 20.000 & 42.700 & 68.600 & 0.4800 & 1.6330 & 0.7410 & 0.1110 & 0.0540 & 1.8800 \\
\hline Mean & 5 & 25.450 & 25.800 & 12.700 & 24.400 & 50.380 & 0.304 & 1.081 & 95.592 & 0.077 & 0.031 & 1.330 \\
\hline Median & 4.85 & 23.950 & 25.900 & 11.950 & 18.300 & 43.200 & 0.284 & 1.126 & 0.591 & 0.077 & 0.030 & 1.270 \\
\hline Sekwness & 0.537 & 0.119 & -0.119 & 0.118 & 0.500 & 0.427 & -0.0330 & -0.2640 & 1.3610 & -0.0990 & 0.0720 & \\
\hline
\end{tabular}

Results from Table 5 and 6 shows that, in both the bakery and domestic boreholes (in Ovia- North East LGA) water quality parameters, a high positive correlation (0.99) exist between TDS and EC; $\mathrm{NH}_{4} \mathrm{~N}$ and TDS. Also, a high negative correlation (0.80) exists between Temp. and EC; TDS and Temp.; $\mathrm{NH}_{4} \mathrm{~N}$ and Temp. The positive correlations existing between parameters implies that they might be of the same source and that they increase and decrease together (Izeze and Adipere, 2018), thus this might help to trace the source of the slight amount of these parameters present in the water. Also the strong positive correlation relationship between $\mathrm{NH}_{4} \mathrm{~N}$ and TDS might be an indication that the groundwater is prone to contamination by anthropogenic activities. Similar strong positive correlation existing between groundwater quality parameters was reported by Omorogieva et al. (2016) for water quality in Okhuahe Community in Edo State, Nigeria and Umamaheswari et al. (2015) for groundwater quality in Gudiyattam and Vaniyambadi blocks of Vellore district, Tamil Nadu, India. 
Table 6: Pearson's correlation matrix for domestic boreholes water quality parameters

\begin{tabular}{|c|c|c|c|c|c|c|c|c|c|c|c|c|}
\hline Parameters & pH & EC & Temp. & TDS & $\mathrm{HCO}_{3}^{-}$ & $\mathrm{Cl}$ & $\mathbf{N H}_{4} \mathbf{N}$ & $\mathbf{F e}$ & $\mathbf{Z n}$ & $\mathbf{P b}$ & Cd & TH \\
\hline pH & 1 & & & & & & & & & & & \\
\hline $\mathrm{EC}(\boldsymbol{\mu S} / \mathrm{cm})$ & -0.4841 & 1 & & & & & & & & & & \\
\hline Temp $\left({ }^{\circ} \mathrm{C}\right)$ & 0.4064 & -0.8028 & 1 & & & & & & & & & \\
\hline TDS (mg/L) & -0.4531 & 0.9934 & -0.8389 & 1 & & & & & & & & \\
\hline $\mathrm{HCO}_{3}-(\mathrm{mg} / \mathrm{L})$ & -0.4531 & 0.9804 & -0.7264 & 0.9655 & 1 & & & & & & & \\
\hline $\mathrm{Cl}(\mathrm{mg} / \mathrm{L})$ & -0.2988 & 0.8682 & -0.7000 & 0.8592 & 0.7789 & 1 & & & & & & \\
\hline $\mathrm{NH}_{4} \mathrm{~N}(\mathrm{mg} / \mathrm{L})$ & -0.4583 & 0.9767 & -0.8906 & 0.9924 & 0.9259 & 0.8647 & 1 & & & & & \\
\hline $\mathrm{Fe}(\mathrm{mg} / \mathrm{L})$ & -0.4832 & 0.9713 & -0.6926 & 0.9388 & 0.9646 & 0.8767 & 0.9049 & 1 & & & & \\
\hline $\mathrm{Zn}(\mathrm{mg} / \mathrm{L})$ & -0.6020 & 0.9824 & -0.7351 & 0.9606 & 0.9610 & 0.8598 & 0.9376 & 0.9809 & 1 & & & \\
\hline $\mathrm{Pb}(\mathrm{mg} / \mathrm{L})$ & -0.6770 & 0.9354 & -0.6207 & 0.9109 & 0.9240 & 0.7892 & 0.8754 & 0.9349 & 0.9770 & 1 & & \\
\hline $\mathrm{Cd}(\mathrm{mg} / \mathrm{L})$ & -0.6165 & 0.8782 & -0.4872 & 0.8375 & 0.8599 & 0.8253 & 0.7954 & 0.9228 & 0.9411 & 0.9707 & 1 & \\
\hline TH (mg/l) & -0.0146 & 0.7329 & -0.8962 & 0.7927 & 0.6664 & 0.6893 & 0.8369 & 0.5977 & 0.6062 & 0.4786 & 0.3786 & 1 \\
\hline Min & 4.700 & 11.200 & 27.100 & 5.500 & 10.100 & 35.500 & 0.114 & 0.311 & 0.187 & 0.030 & 0.008 & 0.4700 \\
\hline Max & 5.300 & 27.900 & 27.400 & 12.600 & 30.500 & 50.900 & 0.360 & 1.480 & 0.584 & 0.055 & 0.036 & 1.7700 \\
\hline Mean & 5.033 & 17.4667 & 26.867 & 8.500 & 16.933 & 40.633 & 0.226 & 0.617 & 0.3242 & 0.0537 & 0.0163 & 1.0467 \\
\hline Median & 5.100 & 16.100 & 26.950 & 8.050 & 15.250 & 39.350 & 0.208 & 0.474 & 0.2925 & 0.049 & 0.013 & 0.9250 \\
\hline Sekwness & -0.2905 & 0.7418 & -0.0648 & 0.4749 & 0.7868 & 0.4763 & 0.2977 & 1.1539 & 0.9952 & 0.8596 & 1.0136 & \\
\hline
\end{tabular}

Results from Table 7 indicated that the WQI range from excellent to good. It was observed that $\mathrm{DBH}_{1}$ and $\mathrm{BBH}_{2}$ fall in the excellent category with WQI values of 15.336 and 22.288 while the rest sample points fall in the good category with WQI values greater than 25 and less than50 (as indicated in Table 7 above). The water quality type was determined based on the weighted arithmetic method classification table (Table 2). The WQI of all water samples which range from excellent to good suggest that the water is suitable for drinking, domestic and industrial (bakery) use. Although all borehole water samples (both domestic and bakery) had excellent and good water quality, the slightly high WQI values (within the range of 25-50) that was observed in some borehole water samples is an indication that the groundwater is prone to contamination by anthropogenic activities. Almost similar range of WQI values (9.17-10.40) and (11.24-16.15) were reported by Egun and Ogiesoba-Eguakun (2018) and Oboh and Agbala (2017) for water bodies in Edo State, Nigeria. However, Omorogieva et al. (2016) reported high WQI values (78.38-95.58) and (112.27-103679.10) for river and some selected boreholes water samples in Okhuahe Community in Edo State, Nigeria. These WQI values are indicative of very poor and unsuitable drinking water quality which according to the author is attributable to the unprotected landfill at the centre of the study site. Also, Etim et al. (2013) reported high WQI values (55.05-84.94) for some water bodies in the Niger Delta region, which is an indication of poor drinking water quality attributable to the exploration and refining of crude oil in the region (Egun and Ogiesoba-Eguakun, 2018).

Table 7: Water Quality Index (WQI) of groundwater samples

\begin{tabular}{ll}
\hline Groundwater Sample Points & WQI of Groundwater Samples \\
\hline $\mathrm{DBH}_{1}$ & 15.336 \\
$\mathrm{DBH}_{2}$ & 29.183 \\
$\mathrm{DBH}_{3}$ & 29.164 \\
$\mathrm{DBH}_{4}$ & 33.388 \\
$\mathrm{DBH}_{5}$ & 36.198 \\
$\mathrm{DBH}_{6}$ & 37.664 \\
$\mathrm{BBH}_{1}$ & 36.292 \\
$\mathrm{BBH}_{2}$ & 22.288 \\
$\mathrm{BBH}_{3}$ & 34.848 \\
$\mathrm{BBH}_{4}$ & 31.956 \\
$\mathrm{BBH}_{5}$ & 29.445 \\
$\mathrm{BBH}_{6}$ & 27.760 \\
\hline \multicolumn{2}{c}{}
\end{tabular}

\subsection{Conclusions}

This study has assessed the impact of urbanizing Ovia- North East LGA of Benin City on the groundwater quality (for its domestic and industrial purpose) using WQI. Results of physiochemical analysis revealed that of all the parameters examined $\mathrm{pH}, \mathrm{Pb}$ and $\mathrm{Cd}$ were not within acceptable limits. The correlation matrix indicated that TDS shows a highly positive correlation (0.99) between 
EC and $\mathrm{NH}_{4} \mathrm{~N}$ respectively and also Temperature shows a highly negative correlation $(0.80)$ between $\mathrm{EC}$, TDS and $\mathrm{NH}_{4} \mathrm{~N}$ respectively. The WQI indicated that the groundwater quality ranged from excellent to good. Although, the groundwater quality in Ovia- North East LGA ranged from excellent to good indicating that it is fit for drinking, domestic and industrial purposes, however the physiochemical and correlation analyses have revealed that the groundwater quality has slightly deteriorated and might be prone to contamination either by natural or anthropogenic activities. Hence, it is suggested that there should be regular monitoring of the groundwater quality in OviaNorth East LGA of Benin City and that the groundwater should be treated before use.

\section{References}

Adegbite, J.T., Aigbogun, C. O. and Kuforijimi, O. (2018). Physiochemical analysis of the quality of groundwater in Egbeta, Ovia North East Local Government Area of Edo State, Nigeria. Journal of Applied Geology and Geophysics, 6(3), pp. 9-32.

Akinbo, F. O. and Okaka, C. E. (2010). Hyperendemicity of onchocerciasis in Ovia North-East Local Government Area, Edo State, Nigeria. East African Journal of Public Health, 7(1), pp. 84-86.

Akpoveta, O. V., Okoh, B. E. and Osakwe, S. A. (2011). Quality assessment of borehole water used in the vicinities of Benin City, Edo State and Agbor, Delta State of Nigeria. Current Research in Chemistry, 3, pp. 62-69.

American Public Health, APHA (1985). Standard methods for the examination of water and waste water, 16th edition. American Public Health Association (APHA), Washington DC, USA.

American Public Health, APHA (1998). Standard methods for the examination of water and wastewater, 19th edition. American Public Health Association (APHA), Washington DC, USA.

Balogun, V. S. and Orimoogunje, O. O. I. (2015). An assessment of seasonal variation of air pollution in Benin City, Southern Nigeria. Atmospheric and Climate Sciences, 5, pp. 209-218.

Brown, R. M., Mccleiland, N. J., Deiniger, R. A. and O'Connor, M. F. A. (1972). Water quality index - crossing the physical barrier (SH Jenkis Ed.) Proc. Intl. Conf. on Water Poll. Res. Jerusalem, 6, pp. 787-797.

Chan, C. L., Zalifah, M. K. and Norrakiah, A. S. (2007). Microbiological and physiochemical quality of drinking water. The Malaysian Journal of Analytical Sciences, 11 (2), pp. 414 - 420.

Christopher, O. A. and Olatunji, O. (2018). Quality assessment and classification of Ogbese river using water quality index (WQI) tool. Sustainable Water Resources Mnagemnet, 4, pp.1023-1030.

Conant, J. B., Cherry, J. A. and Gillham, R. W. (2004). A PCE groundwater plume discharging to a river: influence of the streambed and near river zone on contaminant distributions. J. Contam. Hydrol., 73, pp.249-279.

Egun, N. K. and Ogiesoba-Eguakun, C. U. (2018). Physico-chemical and water quality index analysis of the Okhuaihe river, Edo State, Nigeria. African Journal of Aquatic Science, 43 (4), pp. 345-351.

Erah, P. O., Akujieze, C. N. and Oteze, G. E. (2002). The quality of groundwater in Benin City: A baseline study on inorganic chemicals and microbial contaminants of health importance in boreholes and open wells. Tropical Journal of Pharmaceutical Research, 1(2), pp.75-82.

Etim, E. E., Odoh, R., Itodo, A. U., Umoh, S. D. and Lawal, U. (2013). Water quality index for the assessment of water quality from different sources in the Niger Eelta Region of Nigeria. Frontiers in Science. 3, pp. 89-95.

Foka, F. E. T.,Yah, C. S. and Bissong, M. E. A. (2018). Physio-chemical properties and microbiological quality of borehole water in four crowded areas of Benin City, Nigeria, during rainfalls. ShirazE-MedJ, 19(11), pp. e68911. 
Gogtay, N. J. and Thatte, U. M. (2017). Principles of correlation analysis. Journal of the Association of Physicians in India, 65, pp.78-81.

Ikhile, C. I. (2016). Geomorphology and hydrology of the Benin region, Edo State, Nigeria. International Journal of Geosciences, 7, pp.144-157.

Karunakaran, V. (2008). Study of water quality in and around Vriddhachalam in Cuddalore District, Tamil nadu. Nature Environment. \& Pollution. Technology, 7(4), pp. 635-638.

Khwaja M. A. and Aggarwal, V. (2014). Analysis of groundwater quality using statistical techniques: a case study of Aligarh (India). International Journal of Technical Research and Applications, 2(5), pp.100-106.

Kumar, M. and Kumar, R. (2013). Assessment of physic-chemical properties of groundwater in granite mining areas in Goramachia, Ilansi, UP, India. International Research Journal of Environmental Sciences, 2(1), pp. $19-24$.

Mohamed, A. Z. (2015). Correlation and regression analysis. the statistical, economic and social research and training centre for islamic countries (SESRIC), pp. 1-5.

Mohammad, S. G. and Amba, S. (2018). Groundwater quality assessment of urban Bengaluru using multivariate statistical techniques. Applied Water Science; 8:43.

Mukherji, A. (2006). Intensive use of groundwater, a solution to world's water crisis, UK. Chapter 11, pp. 181-193.

National Groundwater Association (NGWA), 2019. Groundwater foundation. available from: www.groundwater.org/get-informed/basics/groundwater.htlm [Accessed 21 January,2019].

Nicole, M. B., Robin, W., Christian, M. and Mario, S. (2019). A Review of treat to groundwater quality in the anthropocene. Science of the Total Environment, 684, pp. 136-154.

Oboh, I. P. and Agbala, C. S. (2017). Water quality assessment of the Siluko River, Southern Nigeria. African Journal of Aquatic Science, 42 (3), pp. 279-286.

Ogbeifun, D. E., Archibong, U. D., Chiedu, I. E. and Ikpe, E. E. (2019). Assessment of the water quality of boreholes in selected areas in Benin City, Edo State, Nigeria. Chemical Science International Journal, 28(2), pp.1-13.

Ogendegbe, K. and Akinbile, C. O. (2004). Impact of industrial pollutants on quality of ground and surface water at Oluyole Industrial Estate Ibadan. Nigerian J Technol. Dev., 4(2), pp. 139-144.

Omoigberale, M. O., Ogbeibu, A. E. and Olotu, N. O. (2009). Assessment of groundwater quality of Benin City, Edo State, Nigeria. Tropical Freshwater Biology, 18(2), pp. 11-20.

Omorogieva, O. M., Imasuen, O. I., Isikhueme, M. I., Ehinlaye, O. A., Anegbe, B. and Ikponmwen, M. O. (2016). Hydrogeology and water quality assessment (WQA) of Ikhueniro and Okhuahe using water quality index (WQI). Journal of Geography, Environment and Earth Science International, 6(3), pp.1:10.

Orjiekwe, C. L., Dumo, D. T. and Chinedu, N. B. (2013). Assessment of water quality of Ogbese River in Ovia North-East Local Government Area of Edo State, Nigeria. Int. J. Biol. Chem. Sci., 7(6), pp. 2581-2590.

Osei, P. (2004). Water quality of boreholes and hand-dug wells at Pakyi no. 1 in the Amansie West District of Ashanti Region of Ghana. Kwame Nkrumah University of Science and Technology, Kumasi, Ghana. 
Paiu, M. and Breaban, I. G. (2014). Water quality index - an instrument for water resources management. Aerul şi Apa: Componente ale Mediului, pp. 391-398.

Patil, M. B., Deshpande, A. V. and Korake, S. A. (2015). Interpretation of groundwater quality using statistical analysis from Kopargaon, Maharashtra, India. International Journal of Latest Trends in Engineering and Technology, 6(2), pp. 97-104.

Pius, A., Jerome, C. and Sharma, N. (2012). Evaluation of groundwater quality in and around Peenya industrial area of Bangalore, South India using GIS techniques. Environ Monit Asses, 184(7), pp. 4067-4077.

Shweta, T., Bhavtosh, S., Prashant, S. and Rajendra, D., (2013), Water quality assessment in terms of water quality index. American Journal of Water Resources, 1 (3), 34-38.

Tyagi, S., Sharma, B., Singh, P. and Dobhal, R. (2013). Water quality assessment in terms of water quality index. American Journal of Water Resources, 1, pp. 34-38.

Umamaheswari, J., Anjali, R., Abinandan, S., Shanthakumar, S., Ganapathy, G. P. and Kirubakaran, M. (2015). Assessment of groundwater quality using GIS and statistical approaches. Asian Journal of Earth Sciences, 8 (4), pp. 97-113.

Umar, R. and Absar, A. (2003). Chemical characteristics of groundwater in parts of the Gambhir river basin, Bharatpur district, Rajasthan, India. Environmental Geology, 44, pp.535-544.

United State Environmental Protection Agency (USEPA) (2000). Low impact development (LID): a literature review. Office of Water, Washington DC, EPA-841-B-00-005.

Usman, N. U., Mohd, E. T., Hafizan, J., Musa, G. A. Ali, A. R. and Hamza, I. (2014). Assessment of groundwater quality using multivariate statistical techniques in Terengganu. Science and Technology, 4(3), pp. 42-49.

\section{Cite this article as:}

Rawlings A. and Ikediashi A. I., 2020. Impact of Urbanizing Ovia-North East on the Quality of Groundwater using Water Quality Index. Nigerian Journal of Environmental Sciences and Technology, 4(1), pp. 87-96. https://doi.org/10.36263/nijest.2020.01.0180 